УДК:378.091.2:378.022

DOI:

Наталія Науменко, кандидат педагогічних наук, викладач кафедри педагогіки і психології Національного фармацевтичного університету

\title{
ІНФОГРАФІКА ЯК МЕТОД АКТИВІЗАЦІЇ ПІЗНАВАЛЬНОЇ ДІЯЛЬНОСТІ МАГІСТРІВ ОСВІТНІХ, ПЕДАГОГІЧНИХ НАУК
}

У статті розглянуто проблему активізації пізнавальної діяльності магістрів освітніх, педагогічних наук в процесі професійної підготовки за допомогою інноваційних форм та методів навчання, сучасних педагогічних технологій та нетрадиџійних способів засвоєння інформаиіі. Схарактеризовано сутність методу інфографіка та зазначено можливості інфографіки для засвоєння та узагальнення теоретичного матеріалу. Охарактеризовано метод як багатофункціональний інструмент, який можна використовувати під час заняття, виконання проекту, дослідницької діяльності.

Ключові слова: активізачія пізнавальної діяльності; професійна підготовка магістрів освітніх, педагогічних наук; проектні методи; інфографіка; дослідницька діяльність.

Лim. 10.

Nataliya Naumenko, Ph.D.(Pedagogy), Lecturer of the Pedagogy and Psychology Department National University of Pharmacy

\section{INFOGRAPHICS AS A METHOD FOR COGNITIVE ACTIVITY ACTIVATION OF MASTERS OF EDUCATION, PEDAGOGY SCIENCES}

The article considers the problem of activation of cognitive activity for education employees of different levels on the basis of principles of masters of education, pedagogy sciences in the process of professional training with the aid of innovation forms and methods of learning, modern pedagogical techniques and non-traditional methods of acquisition of information that allow the receivers of education to perfect their professional, psychological and pedagogical, communicative competencies; to develop professionally important and personal qualities; to master new mechanisms of applying the innovation educational activity into higher education institutions; to form the theoretical and methodological provision of competitiveness of innovation development. The essence of the infographics method was characterized, which is directed to efficient visual information presentation and its further comprehension in order to briefly and brightly reflect certain facts, processes or events and is a creative projection method of learning at diverse higher education institutions. Possibilities of infographics were stated for elaborating the theoretical material and mastering it through the dominating intellect type. The method was characterized as a multi-functional tool which can be used during classes, project execution, and research activity, self-education to develop proactivity, creativity, critical thinking, and forming skills of efficient interaction. Theoretical and practical aspects of infographics were used during practical classes during professional training of masters of education, pedagogy sciences. Expediency of infographics method was proven concerning its possibility to use in an educational process of professional training of future instructors as an efficient method of activation of receivers of education cognitive activity, which enables better acquisition of information, optimizing independent work of graduate students, intensification of educational process, provides creative, research related direction to training and cognitive activity and allows to see the result of own educational activity.

Keywords: an activation of cognitive activity; professional training of masters of education; pedagogy sciences; project methods; infographics; research activity.

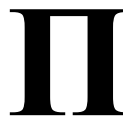
остановка проблеми у загальному вигляді та її зв'язок із важливими науковими чи практичними завданнями. Перебудова системи вищої освіти України спрямована на реалізацію завдань держави та суспільства щодо ефективної професійної підготовки компетентних, конкурентноспроможніх фахівців, здатних інноваційно й творчо мислити, вирішувати складні професійні завдання, бути адаптованими до дій у нових ситуаціях, працювати в команді. Такі вимоги визначають пошук та впровадження в освітній процес сучасних педагогічних технологій, інноваційних форм та методів навчання, нетрадиційних способів засвоєння інформації.

Аналіз основних досліджень і публікацій, в яких започатковано розв'язання даної проблеми. Аналіз психолого-педагогічної літератури та наукових публікацій з проблеми активізації пізнавальної діяльності студентів у закладах вищої освіти дозволив визначити її актуальність та ступінь досліджуваності науковцями, оскільки вирішення даного питання уможливлює підвищення ефективності, результативності та якості освітнього процесу. В своїх наукових працях питання активізації 
пізнавальної діяльності порушували видатні психологи та педагоги.

Психолого-педагогічні аспекти пізнавальної діяльності висвітлені у працях Л. Арістової, Л. Виготського, П. Гальперіна, В. Давидова, О. Леонтьєва, С. Рубінштейна, Н. Тализіної; активізацію мислення студентів в контексті проблемного навчання порушено в працях Г. Костюка, І. Лернера, В. Лозової, М. Махмутової, П. Лузана [5]; формування пізнавальних потреб вивчали Г. Костішина, Г. Щукіна, М. Махмутов, П. Гальперін; розвиток творчих здібностей особистості, пізнавального інтересу, самостійного отримання знань через вирішення пізнавальних задач розглядали В. Бондар, І. Зязюн, Н. Ничкало, В. Паламарчук, О. Савченко.

Т. Шамова пізнавальну активність розглядає як якість навчально-пізнавальної діяльності особистості та невід'ємною їі характеристикою, а пошук шляхів підвищення активності здобувачів освіти у процесі навчання виступає як важливе завдання педагогічної науки й практики [8].

А. Вербицький, В. Мороз, Т. Тернавська та багато інших дослідників ведуть інтенсивний пошук ефективних форм та методів організації навчального процесу 3 метою формування пізнавальної діяльності студентів [3, 6, 7].

У своїх дослідженнях Я. Ягупов визначає методи активізації навчально-пізнавальної діяльності як “сукупність прийомів і способів психолого-педагогічного впливу на учнів, які порівняно $з$ традиційними методами навчання, у першу чергу, спрямовані на розвиток у них творчого самостійного мислення, активізацію навчально-пізнавальної діяльності, формування незвичних навичок та вмінь нестандартного розв'язання певних професійних проблем i вдосконалення навичок професійного спілкування" [10].

Зокрема, Ю. Бабанський визначає групу методів, що активізують пізнавальну діяльність здобувачів освіти, як “активні методи навчання чи методи активного навчання" [2].

Аналіз наукових публікацій та власний досвід професійної підготовки магістрів освітніх, педагогічних наук дозволив визначити, що, незважаючи на інтерес педагогічної спільноти до проблеми активізації освітньої діяльності студентів, розвитку їхнього пізнавального інтересу, творчого та інноваційного мислення, питання активізації пізнавальної діяльності здобувачів освіти за спеціальністю “освітні, педагогічні науки” під час їхньої професійної підготовки залишається малодослідженим. Розуміння сутності пізнавальної діяльності майбутніх викладачів закладів вищої освіти сприяло розгляду питання про застосування інноваційних форм та методів її активізації на практичних заняттях під час вивчення дисципліни “Дидактичні системи та педагогічні технології у вищій освіті”.

Формування мети статті. Метою статті $€$ висвітлення теоретичних і практичних аспектів застосування інфографіки на практичних заняттях у професійній підготовці магістрів освітніх, педагогічних наук та визначення значення цього метода для ефективного засвоєння інформації під час вирішення пізнавальних задач.

Виклад основного матеріалу дослідження 3 повним обгрунтуванням отриманих наукових результатів. Професійна підготовка магістрів освітніх, педагогічних наук на кафедрі педагогіки та психології Національного фармацевтичного університету сприяє вдосконаленню професійної та формуванню психолого-педагогічної, комунікативної компетентностей; розвитку професійно важливих та особистісних якостей сучасних викладачів закладів вищої освіти; опануванню ними механізмами застосування інноваційної освітньої діяльності у вищій школі; формуванню теоретикометодичного забезпечення конкурентноспроможності працівників освіти різних рівнів на основі принципів інноваційного розвитку. Постійна трансформація знань, самоосвіта, самовдосконалення та саморозвиток впродовж життя стає необхідною умовою для конкурентноспроможного фахівця. 3 огляду на це змінюється підхід до освітньої діяльності у закладах вищої освіти, що визначається застосуванням інноваційних форм та методів отримання та засвоєння інформації.

В умовах сьогодення в процесі професійної підготовки магістрів освітніх, педагогічних наук на кафедрі педагогіки та психології під час практичних занять активно використовуються елементи сучасних інформаційних технологій, які постійно вдосконалюються в своїй якості. Серед таких методів, спрямованих на ефективну візуальну презентацію інформації та іiі подальше осмислення, $є$ інфографіка.

За визначеннями зарубіжних публікацій, цей метод розуміється як візуальне комплексне подання текстової або графічної інформації з метою стислого і яскравого відображення певного факту, процесу, події [1].

Значне розповсюдження цей метод отримав в засобах масової інформації, мережі Інтернет, рекламі, соціології, економіці. Нещодавно інфографіка стала відомою в новій якості - як творчий проектний метод навчання у різнопрофільних закладах вищої освіти. 

ПЕДАГОГІЧНХОАУК

Термін "інфографіка" походить від поєднання двох американських слів "Information" i "Grafics" - "Infografics", що варто тлумачити як "графізм інформації”. Таким чином, інфографіка - просте та наочне графічне подання інформації про предмети, включаючи складні взаємозв'язки між ними та інтеграція різних складових в єдине ціле [4]. У більш вузькому розумінні інфографіка являє собою лаконічний інформаційний матеріал, який ілюструє текстову публікацію. На сучасному етапі розвитку інформаційних технологій у мережі Інтернет існує багато сервісів для створення інфографіки: інтерактивні дошки, хмари ключових слів, карти понять, інтерактивні карти. Проте інфографіку можна створити за допомогою простих інструментів: ватману, олівця, маркера, лінійки.

Сьогодні, в період інформаційного вибуху, актуальності набуває наочне представлення інформації, даних і знань через ілюстрації. Це пов' язане з тим, що більшість людей орієнтовані i легше сприймають візуальні образи зображення, схеми, колажі, і в меншому ступені - текст.

В своєму дослідженні О. Швед проаналізувала приклади освітньої інфографіки та визначила три рівні візуалізації:

- візуалізація даних - надає можливість прочитати цифри, що $€$ трансформацією масиву даних в діаграми та дозволяе побачити закономірності;

- візуалізація інформації (інфографіка в “чистому вигляді") - поєднує різноманітні факти історії, пропонуючи інтерпретацію подій;

- візуалізація знань - комунікація інфографіки звертається до вже наявних знань та досвіду користувача, мета дизайну є провідником на шляху вибору траєкторії сприйняття інформації [9].

Візуальні образи як комунікаційні засоби відіграють важливу роль в презентації ідей. Трансформуючи багатослівні тексти та спрощуючи зміст матеріалу, вони водночас здатні передати всю необхідну інформацію, інтегруючи факти, процеси, зв'язки та висновки. Інфографіка являє собою категорію зображень, в яких комунікативні можливості вищі.

Навчальна дисципліна “Дидактичні системи та педагогічні технології у вищій освіті” є однією 3 фундаментальних дисциплін, яка входить до навчального плану професійної підготовки магістрів освітніх, педагогічних наук. Навчальною програмою передбачено вивчення дванадцяти ключових тем, які визначають знання, вміння та навички щодо специфіки планування та організації навчально-виховного процесу в умовах закладу вищої освіти, особливостей форм, методів і засобів організації навчально-виховного процесу в закладах вищої освіти, сутності сучасних освітніх технологій та їх застосування під час проведення різних видів занять.

Кожна тема містить великий обсяг теоретичної інформації та інтегрується з іншими навчальними дисциплінами фахової підготовки сучасних викладачів, таких як "Планування та організація освітнього процесу", "Педагогічна майстерність викладача вищої школи", "Методика викладання у вищій школі" та ін. Для більш ефективного засвоєння навчального матеріалу з подальшим його використанням на практиці під час практичних занять, які були поєднані однією темою, магістранти у групах створювали тематичну інфографіку. Відповідаючи на запропоновані запитання до теми, вони, аналізуючи та узагальнюючи набугі під час лекцій, самостійної роботи знання та дидактичного матеріалу повинні були за допомогою схем, діаграм, зображень та колажів відобразити структурно-логічні зв'язки між поняттями, виділити ключові характеристики кожного з них та презентувати свої творчі проекти перед групою.

Процес створення тематичної інфографіки складався 3 декількох етапів, а саме: формулювання мети та постановка задач; розподіл завдань між членами малих груп; збір даних за темою, представлених у вигляді текстової інформації, дидактичних матеріалів; аналіз та обробка інформації; трансформація та побудова візуалізації. Для визначення, чи $\epsilon$ створений продукт інфографікою, та, відповідно, іiї оцінки, було запропоновано видалити 3 неї весь текст та переглянуги, чи передає зображення, що залишилося, повний зміст роботи. Якщо ні - це ілюстрація.

За даним методом магістранти працювали над темами "Особливості підготовки та проведення лекції”, “Активні та інтерактивні методи навчання", "Готовність педагога до інноваційної професійної діяльності" та "Характеристика сучасних педагогічних технологій”.

На підсумковому практичному занятті 3 дисципліни здобувачі освіти під час узагальнюючої дискусії висловили своє ставлення щодо можливостей застосування методу інфографіки в освітньому процесі та ефективність його для засвоєння, узагальнення та застосування інформації для вирішення професійних завдань. Магістранти зазначили, що інфографіка надає можливість працювати 3 інформацією та засвоювати їі через домінуючий тип інтелекту; 


\section{ІНФОГРАФІКА ЯК МЕТОД АКТИВІЗАЦІЇ ПІЗНАВАЛЬНӦ̈ ДІЯЛЬНОСТІ МАГІСТРІВ ОСВІТНІХ, ПЕДАГОГІЧНИХНАУК}

являє собою багатофункціональний інструмент, який можна використовувати під час заняття, виконання проекту, дослідницької діяльності, самоосвіти; розвиває креативність та критичне мислення; формує навички ефективної взаємодії.

Таким чином, в освітньомупроцесі інфографіку можна використовувати для актуалізації опорних знань на підготовчому етапі практичного заняття, повторюючи основні поняття теми; під час пояснення нового матеріалу, представляючи інформацію у яскравому вигляді, яка більшою мірою має вплинути на емоційну сферу тих, хто навчається; а також, як змістовий або підсумковий контроль, де магістрантам пропонують створити виразну графіку основних понять, що, в свою чергу, активізує їхній пізнавальний процес.

Висновки 3 даного дослідження i перспективи подальших розвідок у даному напрямку. Використання методу інфографіки в освітньому процесі професійної підготовки магістрів освітніх, педагогічних наук носить випереджувальний характер, враховуючи зміни, які сьогодні відбуваються у вищій освіті.

Досвід кафедри педагогіки та психології Національного фармацевтичного університету 3 використання інфографіки підтвердив, що даний метод являє собою ефективний засіб активізації пізнавальної діяльності здобувачів освіти, сприяє кращому засвоєнню інформації, оптимізації самостійної роботи магістрантів, інтенсифікації освітнього процесу, надає навчально-пізнавальній діяльності творчого, дослідницького спрямування та дозволяє бачити результат власної освітньої діяльності. Вважаємо, що результатом подальших наукових розвідок повинно стати дослідження сучасних інноваційних методів навчання в освітньому процесі закладів вищої освіти.

\section{ЛІТЕРАТУРА}

1. Smiciklas M. The Power of Infographics : Using Pictures to Communicate and Connect with Your Audience. Indianapolis, USA. 2012.

2. Бабанский Ю. К. Оптимизация педагогического процесса: в вопросах и ответах : научное издание Киев, $1982.198 \mathrm{c}$.

3. Вербицкий А. А. Активное обучение в высшей школе : контекстный подход : метод. пособие. Москва, $1991.207 \mathrm{c}$.

4. Кубрак Н. В. Мастерская “Инфографика в работе с детьми”. URL: https://sites.google.com/site/infogradeti/ home

5. Лузан П. Г., Дьомін А. І., Рябчик В. І. Формування активності студентів у навчанні : монографія. Київ, 1998. $192 \mathrm{c}$.

6. Мороз В. Д. Активні методи навчання в технікумі. Харків, 1987.27 с
7. Тернавська Т. А. Проблема активізації пізнавальної діяльності в студентів ВНЗ. Наукові записки. Педагогічні, психологічні науки й сочіальна робота. Том 59. 2006. С. 36-42.

8. Шамова Т. И. Активизация учения школьников. Москва, 1982. 208 с

9. Швед О. В. Інфографіка як складова освітньокомунікаційного процесу. Наукові записки : збірник наукових статей. Київ, 2015. Випуск СXXVII(127). С. 224 232.

10. Ягупов В. В. Педагогіка : навчальний посібник. Київ, 2000.489 с.

\section{REFERENCES}

1. Smiciklas, M. (2012). The Power of Infographics : Using Pictures to Communicate and Connect with Your Audience. Indianapolis. [in English].

2. Babanskiy, Yu. K. (1982). Optimizatsiya pedagogicheskogo protsessa : v voprosakh i otvetakh : nauchnoe izdanie [Optimization of a pedagogy process: questions and answers: scientific edition]. Kyiv, 198 p. [in Russian].

3. Verbitskiy, A. A. (1991). Aktivnoe obuchenie v vysshey shkole : kontekstnyy podkhod : metod. posobie [Active teaching in higher school: contextual approach: textbook]. Kyiv, 207 p. [in Russian].

4. Kubrak, N. V. Masterskaya "Infografika v rabote s detmi" [Workshop "Infographics when working with children"]. Available at: https: //sites.google.com/site/ infogradeti/home [in Russian].

5. Luzan, P. H., Domin, A. I. \& Riabchyk, V. I. (1998). Formuvannia aktyvnosti studentiv u navchanni [Forming student activity for studying: monograph]. Kyiv,192 p. [in Ukrainian]

6. Moroz, V. D. (1987). Aktyvni metody navchannia v tekhnikumi [Active methods of teaching at a vocational school]. Kharkiv, 27 p. [in Ukrainian].

7. Ternavska, T. A. (2006.) Problema aktyvizatsii piznavalnoi diialnosti v studentiv VNZ [Problem of activization of cognitive activity for students of higher education establishments]. Scientific notes. Pedagogy, psychological sciences and social work. Vol 59. pp. 3642. [in Ukrainian]

8. Shamova, T. I. (1982). Aktivizatsiya ucheniya shkolnikov [Activization of studying for school students]. Moscow, 208 p. [in Russian].

9. Shved, O. V. (2015). Infohrafika yak skladova osvitno-komunikatsiinoho protsesu. [Infographics as a constituent of educational and communication process] Scientific notes: collection of scientific works. Kyiv, Vol 127. pp. 224-232. [in Ukrainian].

10. Iahupov, V. V. (2000). Pedahohika : navchalnyi posibnyk [Pedagogy: textbook]. Kyiv, 489 p. [in Ukrainian].

\section{Стаття надійшла до редакції 07.06.2019}

